\title{
A SZOCIÁLPSZICHOLÓGIA ÉS HATÁRTERÜLETEI A SZOCIÁLPSZICHOLÓGIA 30 ÉVE
}

\author{
HUNYADY GYÖRGY \\ ELTE Pedagógiai és Pszichológiai Kar, Budapest, Magyarország \\ E-mail: hunyady.gyorgy@ppk.elte.hu
}

Benyújtva: 2021. augusztus 20. - Elfogadva: 2021. augusztus 24.

\begin{abstract}
A szociálpszichológia utóbbi három évtizede a kutatás és a publikációk határozott irányaival jellemezhetố hazánkban. 1) Az elsố tárgykör a szociális identitás különbözố (generációs, nemzeti, kulturális és nemi) aspektusait, ezen makrostrukturális csoportok viszonyait, a müködố sztereotípiákat és a multikulturális nevelést öleli fel. Ezen a széles szaktudományos területen a különbözố egyetemeken és kutatóintézetben folytonos fejlödés ment végbe, az elméleti megközelitések és módszertani megoldások gazdag változatossága mellett. 2) A második nagyobb tematikus egység a változások szociálpszichológiája volt, mind a „kommunizmus bukását" követô társadalmi-politikai változásokra, mind az internet és általában a kommunikációs technológia forradalmi hatásaira kitekintve. 3) A hatékony kutatómunka harmadik fontos területe a személyközi és szervezeti viselkedés dinamikája, kitüntetett figyelemmel az együttmüködés és versengés kontinuumára. 4) A negyedik témakör a személyes értékekhez, ezeknek az egyéni világképben játszott szerepéhez és a nevelés révén végbemenô értékátadáshoz kötôdött. Ebben az idôszakban jelentős kutatásmódszertani fejlôdés ment végbe, és erôsödtek a szociálpszichológia és más társadalomtudományok (a nevelés-, közgazdaság-és jogtudomány) közötti kapcsolatok.
\end{abstract}

Kulcsszavak: tematikus irányok, társadalmi identitás, társadalmi változás, személyközti és szervezeti dinamika, egyéni értékek és az értékek átszármaztatása 


\section{BEVEZETÉS}

A magyar szociálpszichológia a rendszerváltás nyomán felpezsdült, az aktuális társadalmi fejleményekre elôször élénk - zömmel magyar nyelvú, esszéisztikus, könyv formátumú - publikációs terméssel reagált. A korszakos társadalmi változások iránt 90 elôtt felcsapó külföldi érdeklôdés ezt követôen sem enyészett el, elônyeit a hazai szociálpszichológia a nyelvismeret és az alkalmazott kutatásmódszertan szintjének függvényében tudta mindinkább kamatoztatni. A szakterület órizte és gazdagította korábbi tematikáját, minek során kialakultak új súlypontok, és erôteljes, érdemi nyitásra került sor a társ-társadalomtudományok felé. A 90-ben mintegy negyedszázados múltra viszszatekintố törzsterület eleve a nemzetközi tudományossággal való kapcsolatban fogant (lásd a szakszövegek számos és mindinkább koncepciózus gyújteményeit, utóbb a képzést szolgáló lefordított amerikai/európai tankönyveket, de tükrözi ezt az 1997-ben megjelent elsố magyar tankönyv és szöveggyújteménye is (Csepeli, 1997b; Lengyel, 1997), ezért is a hazai társadalomtudományok számottevô részétôl eltérôen az ideológiai monopólium kötelmeinek lehántása itt szükségtelen volt.

A szociálpszichológia területén végbement fejlôdés és elért eredmények tárgyalását négy bekezdésre tagoljuk: 1) E munkálatok törzsét a társadalmi identitás és a csoportközi viszonyok sokrétû témájának folytonos vizsgálata képezte, elméleti-módszertani hátteret biztosítva a más irányú munkálatoknak is. 2) Kezdetben szinte elhatárolhatatlan ettôl, de utóbb önállósodik a társadalmi változások szociálpszichológiai követése, illetve az ezekkel kapcsolatos várakozások kidolgozása. 3) Az interperszonális kapcsolatok dinamikája, legyenek ezek spontánok vagy intézményes keretben szervezettek, hagyományosan centrális kérdésköre a szociálpszichológiának, amely e periódusban számottevô magyar eredményekkel is büszkélkedhet. 4) Ebbe beleszövôdik, ettôl szinte csak mesterségesen választható el az érték- és normatudat és ennek akár spontán, akár céltudatos formálása.

\section{TÁRSADALMI IDENTITÁS, SZTEREOTÍPIA ÉS ELŐÍTÉLET A CSOPORTKÖZI VISZONYOKBAN}

Az identitás tanulmányozása - amely a három évtized szociálpszichológiájának töretlen vonulata volt - egyfelôl a hazafiság/nemzettudat 70-es években indult empirikus megközelítésében gyökerezett, másfelôl a 80-as évektôl változatos formában igyekezett kiaknázni a kulcsfogalomban rejlô elméleti integrációs lehetôségeket, tekintettel az azonosságtudat társadalmi és pszichológiai kettős beágyazottságára és kötöttségére.

Az identitáskutatások kezdetén elmemozgató szerepet játszottak Garai László vitakérdései (1993), melyek a generációs identitás hazai történeti sajátosságait is érintették. Pataki Ferenc a szocializációs-generációs szempontokat személyes és szakmai involváltsággal tárgyalta egymásra épülô több kötetében (Pataki 2001, 2005, 2013). A történeti-leíró munkastílus mellett az identitásra koncentrált munkáját kezdetektôl az elméleti-integratív feladatvállalás jellemzi, ennek az ambíciónak a jegyében behatóan tárgyalta, hogy a szociálpszichológia affektív irányvétele mennyiben befolyásolja a tár- 
sadalmi azonosságtudat korszerú értelmezését (2004). Szellemi örökségének ápolásában aktív szerepet vállalt Csepeli György és László János, az ELTE Szociológiai, illetve az MTA Pszichológiai Intézetében.

A nemzettudat hazai vizsgálatának egyik úttörôje volt Csepeli György, aki ez irányú munkáiban az egyoldalú, felfokozott nemzeti elfogultság esetenként groteszk s mindenkor veszélyes megnyilvánulásaira is korán felhívta a figyelmet (Csepeli 1992, 1997a, 2011), a sokoldalú és hosszú távú lokális vizsgálatai utóbb nemzetközi perspektívában nyerték el mélyebb értelmüket. E folyamat kiteljesedése az 1995-tôl az International Social Survey Programme keretében rendszeres idôközökben megismétlôdó nemzetiidentitás-felmérés az európai országok adatai alapján. Az elemzések - sommás megítélése szerint - azt mutatják, hogy Szúcs Jenô 1981-ben publikált elmélete Európa három fejlődési régiójáról kisebb módosításokkal a 21. század elején is érvényes (Csepeli és Örkény, 2017, 2020).

A kiterjedt mintákon szerzett tudatvizsgálati eredmények hátterében is felsejlett a nemzeti múltra vonatkozó közkeletû narratívumok szerepe. Ezt az összefüggést magas szintû módszertani érzékenységgel és tudatossággal tárgyalta és demonstrálta László János (László 2005, 2008, 2014). Elméleti munkájának fókuszában a narratív pszichológia kidolgozása állt, ehhez kapcsolódóan teremtette meg munkacsoportja - Ehmann Bea különösen aktív közremúködésével - a narratív pszichológiai tartalomelemzés módszertanát, és kifejlesztette annak automatikus eljárását, a NarrCat korpusznyelvészeti keresôalgoritmus-rendszert. Az általa európai kisugárzással képviselt narratív szociálpszichológia empirikus vizsgálatai kitekintettek a magyar nemzeti identitás jellemzôire (úgymint csoportközi ágencia, az értékelés, az érzelmek és kognitív állapotok jelentkezésére) a sajtóból vett szövegkorpuszokban, történelmi regényekben, iskolai tankönyvekben és kísérleti prezentációk fogadtatásában. Ezen eredmények is ráirányították a figyelmet a magyar nemzettudat tartalmát formáló kollektív történelmi traumák feldolgozására, amiben az „áldozati szerep” különösen nagy hangsúlyt kap (mely gondolati irányt László tanítványai a további tájékozódásuk során is követték, lásd Fülöp és Kôvágó, 2018). Jól kiegészítik ezen felismeréseket Kovács Judit és munkatársa eredményei az erkölcsi tartást adó motívumokról (megküzdés, összetartozás, szabadságvágy) a magyar nemzettudat tartalmában (Kovács és Pántya, 2012).

Az identitás problematikája - mint jeleztem - gondolati találkozási pont volt Garai László filozófiai ihletettségú múhelyében is, melynek legtartósabb és a publikációk tanúsága szerint is legtermékenyebb hajtása Erôs Ferenc 30 év során kiteljesedett életmúve volt. Erôs - elsôsorban elemzô-értelmezô jellegú - munkáinak témája volt az analitikus szociálpszichológia, a „freudomarxizmus” kérdésköre, a freudi kultúraelmélet és a frankfurti iskola szempontjait ötvözô, pszichoanalitikus szemléletú társadalomkritika (Erôs 2001b, 2007). Ennek jegyében foglalkoztatta intenzíven az elôítélet, a raszszizmus, a tekintélyelvúség problémája és a „Másik” konstrukciója. A trauma kérdéskörét vizsgáló írásaiban szintén társadalmi jelenségekre alkalmazta a pszichoanalitikus felfogást: a holokauszt, a transzgenerációs traumaátadás hatásaival és a (zsidó) identitás tartalmával, megélésének, elbeszélésének lehetôségével Magyarországon az elsôk között foglalkozott. Történeti perspektívájú munkái (Enyedy és Erôs, 1999; Borgos, Erôs és Litván, 2006; Erôs, Lénárd és Bókay, 2008; Borgos, Erôs és Gyimesi, 2019 vagy 
a forráskiadás kiemelkedô példájaként említhetô Freud-Ferenczi-levelezés sajtó alá rendezése) a pszichológusszakma önismeretét kívánták szolgálni, s az interdiszciplináris kapcsolatépítés szolgálatában álltak és nyernek folytatást.

Az ELTE Pszichológiai Intézetében (majd Pszichológiai és Pedagógiai Karán) a kognitív szociálpszichológia hagyományai erôsek, aminek kulcsfogalma a 80-as, 90-es években a sztereotípia volt, az identitásépités és a csoportközi viszonyok tanulmányozása szempontjából egyaránt releváns konstrukció (Kiss, 2019). A nemi sztereotípiák kulturális sajátosságainak kutatásaival indult Nguyen Luu Lan Anh munkássága, amely egy kutatómúhely forrásvidékévé vált (Nguyen Luu, 2019). Ennek egyik fô csapásiránya az akkulturáció, az identitás témakörét célozza meg. Szakmai érdekkörük az egyre nagyobb számot kitevô „nemzetközi diákok” és a különbözô kisebbségi csoportok (a bevándorlócsoportoktól a német vagy szerb ajkúakon át a romákig) etnikai-kulturális identitásának különbözô szintjeinek feltárásától az identitásnehézségek beazonosításán át az identitás megerôsítéséig terjed. A kutatásaik másik fố irányába tartoznak (Szabó és Kovács, 2017) a nemi szerepek egyéni, csoportos és társadalmi vetületei (nemi sztereotípiák, nemek közötti viszonyok, szexizmus, feminizmus, maszkulinitás), a társadalmi nemek kérdésének vizsgálata különbözô szférában: család és munkahely, iskola és politika. Harmadik fó irányként említhetô az interkulturális nevelés, a multikulturális oktatás, a család és az iskola közötti viszony, a kulturális sokféleség kérdése az iskolában: a tanárok multikulturális, valamint a bevándorlók iránti attitúdjeivel, bevándorló gyerekek iskolai szocializációjával és családjuk akkulturációjával, a tanodába járó gyerekek tanulmányi és társas területen való boldogulásával egyaránt foglalkoznak. (Megjegyzendô, hogy az iskolai szocializáció átfogó keretein belül szociálpszichológiai szempontból releváns képzési tartalmak megalapozása - mint Kovács Mónika koordinációjában a holokauszt tanítása - is a kutatási múhely felvállalt és eredménynyel megoldott feladatai közé tartozik.)

Míg a szociálpszichológiának a nevelés területén való kamatoztatása a fentiekben érintett kutatások nyilvánvaló célja, ezekkel bizonyos átfedéssel, de ugyanakkor markáns politikai pszichológiai profillal, nemzetközi szinten álló empirikus módszertannal, figyelemre méltó publikációs terméssel jelentkezik 2012 után az ELTE egy másik - Kende Anna vezetése alatt álló - kutatómúhelye is. A csoportközi viszonyok és a politikai viselkedés pszichológiai vetületei tanulmányozása itt szorosan kötôdik azokhoz a társadalmi és politikai eseményekhez, amelyek meghatározóak adott idôszakban Magyarországon és a világban. A csoportközi viszonyok közül kiemelt figyelmet szenteltek e kutatások a romák és nem roma magyarok (vagy más európaiak) kapcsolatának, az elôítéletesség kérdéseinek és a hatékony antidiszkriminációs beavatkozásoknak, illetve annak a kérdésnek, hogy milyen mechanizmusok tartják fenn a nemek közötti egyenlôtlenségeket. Emellett több kutatás az idegenellenesség pszichológiai gyökereit vizsgálta, mégpedig a nemzeti identitás sajátosságaiban, a morális beállítódásban és a konvenciókhoz, meglévô társadalmi hierarchiákhoz való ragaszkodásban keresve magyarázatot e jelenségre (Kende és mtsai, 2020; Hadarics és Kende, 2019). E múhelyhez köthetjük Krekó Péter politológiai megközelítést is érvényesítô munkásságát is, amely többek között az elôítéletesség egyik aleseteként az „összeesküvés-elméletek” monografikus vizsgálatát nyújtja (Krekó, 2018). 


\section{A VÁLTOZÁS TÖRTÉNETI SZOCIÁLPSZICHOLÓGIÁJA ÉS A JÖVÔBE MUTATÓ VÁLTOZÁSOK}

A rendszerváltás értelemszerúen magára vonta a szociálpszichológusok szakmai figyelmét, akik a módszertani individualizmus jegyében fogant empirikus eszközeikkel ritkán, az egyénrôl a társadalomra futó fogalmi apparátusukkal gyakrabban próbálták megragadni az átfogó makrostrukturális folyamatot, ennek elôzményeit és következményeit. A megnevezett identitáskutatók (nemegyszer identitásváltásként könyvelve el a történteket) aktív szerepet játszottak a hazai és nemzetközi tekintetben egyaránt éló és ható téma tárgyalásában. Így járt el a maga túlhangsúlyozott marxista identitását elhalványító Garai László, vélhetốen ebben talált rá igazán a maga szakmai identitására Erôs Ferenc (Erôs, 1993, 2001a), de a maga esszéisztikus múfajában figyelemre érdemes tanulmányokat írt Halász László (Halász, 1992), aki egyébként a múvészetpszichológia útkeresô képviselőjeként méltán tekinthetô a narratív megközelítés szálláscsinálójának. A legnagyobb visszhangot Pataki Ferenc kiemelkedő, politikai érzékenységú írásai váltották ki, aki szakmai gondolati keretben tudta árnyaltan kezelni a történeti felelôsség kényes kérdéseit is (Pataki, 1993, 2000), amint aztán folytatólagosan is szakmailag kommentálta a Fidesz-korszakig bekövetkezô társadalmi-politikai változásokat is (Pataki, 2011).

Hunyady György tevékeny szerepet játszott a kognitív szociálpszichológia alapfogalmainak (attitûd, személy és csoportpercepció) meghonosításában mind az oktatás, mind a kutatómunka területén. Így volt egyik hazai úttörôje a nemzettudattal összefonódott sztereotípiák módszeres feltárásának. Unikális érdeklôdést árult el a sztereotípiák rendszerszerú szervezôdése iránt egyéni és társadalmi szinten, feltételezve és dokumentálva, hogy ezek rendszerében az egyéni gondolkodási stílus és az ideologikus közgondolkodás jelenik meg. Ez a megközelítés tette lehetôvé számára, hogy a sztereotípiák rendszerében („implicit társadalomelméletben”) a rendszerváltáskor sebesen bekövetkezó változásokat feltárja nemzeti, társadalmi és történeti vetületben egyaránt (Hunyady, 1996 és angolul 1998a, 1998b). Hunyady erôfeszítéseket tett, hogy a szociálpszichológia klasszikusait és az ezredforduló idején fellépô radikális megújítóit kiadványsorozatokban ismertesse meg a hazai szakmai és tágabb értelmiségi olvasóközönséggel (lásd Hunyady, 2006). Ezzel összhangban módszeres vizsgálatok közel két évtizedes sorozatával vette célba (a megújuló szociálpszichológia makrostrukturális és motivációs szempontjaiból) a társadalmi viszonyok megélésének ellentmondásos tapasztalati anyagát, kritikusan elutasító és igazodóan elfogadó jellegét és ezek - politikai pszichológiai szempontból is releváns - társadalmi-közérzeti hullámverését (Hunyady, 2002, 2018). A közgondolkodás és a társadalmi közérzet módszeres vizsgálata szempontjából kiemelt figyelmet érdemelnek Münnich Ákosnak a matematika társadalomtudományi alkalmazásába nemzetközi viszonylatban jól beágyazott kutatásai akár az ítéletek/attitûdök (Münnich, Maksa és Mokken, 1999), akár az életminôség feltárására (Münnich, 1995). Fülöp Márta a rendszerváltás egyik kulcsfogalmának, a versengésnek a percepcióját vizsgálta és találta azt, hogy a versengés megítélése még a serdülő és fiatal felnôtt korosztályban is negatív volt még azok között is, akik a piacgazdaságra célzott felkészítésben vettek részt (Fülöp, 2002, 2005). 
A szociálpszichológusoknak - ha elốre vetik tekintetüket - józanul számolniuk kell azzal, hogy az információkezelés forradalmi megújulása már eddig is, a jövôben pedig mind nagyobb mértékben változást hoz a társas-társadalmi kapcsolatokban, ezek metszéspontjában az egyén megélt helyzetében és a technikai fejlôdés következtében az embernek intelligenssé váló eszközeihez és önmagához fưzôdô viszonyában. Az internet pszichológiai kutatásában szerepet vállaltak Kende Anna és munkatársai, különösképpen a problémakör meghonosításában és módszeres vizsgálatában úttörố szerepet játszó Ujhelyi Adrienn (lásd az Alkalmazott Pszichológia 2014. évi tematikus számát, Ujhelyi, 2014). Példaként idézhetjük a hálózatkutatás ígéretes terepét, amelyen az internethasználat és a közösségi média adekvát indikátorként szolgálhat (Pléh és Unoka, 2016). Tág társadalmi-kulturális kontextusban szisztematikusan foglalkozik e kérdéskörrel Csepeli és munkatársának monográfiája (Csepeli és Prazsák, 2010), ugyanố a mesterséges intelligencia társadalmi és gazdasági kihatásának átgondolt monográfiát szentelt (Csepeli, 2020). Tevékeny részese annak az ELTE-n szociológiai keretben folyó kutatássorozatnak, amely a digitális adatrobbanás nyomán végbemenó társadalmi változások szociálpszichológiai vetületével foglalkozik, a kutatás kulcsszavai: a mikrocelebritások jelensége, a politikai elkötelezôdés és részvétel, valamint a társadalmi mozgalmak mintázatai, melyeket rendre a digitalitás által létrejött új eszközök segítségével vizsgáltak (Dessewffy, 2019).

\section{AZ INTERPERSZONÁLIS ÉS SZERVEZETI KAPCSOLATOK DINAMIKÁJA}

Az országban a rendszerváltozás során végbement változások elvben és gyakorlatban a figyelem elôterébe állították az emberek közötti versengés - tulajdonképpen az együttmúködés kérdéseihez képest szakmatörténeti szempontból elhanyagolt - problematikáját. Ennek vizsgálatában azonban ez időre Fülöp Márta - egyetemi stúdiumai óta halmozódó - széles körú tájékozottsággal, kreatív koncepcionális megfontolásokkal és empirikus tapasztalatokkal rendelkezett. Fülöp Márta újraértelmezte a szociálpszichológián belül uralkodó dichotóm nézetet az együttmúködés és versengés viszonyáról, és elsôként írta le és helyezte el operacionalizálható dimenziók mentén a konstruktív és a destruktív versengést (Fülöp, 1992). Ezen fogalmak azóta a nemzetközi szakirodalomban teret nyertek a versengési folyamatok kutatásában és értelmezésében. Nevéhez fưzôdik az együttmúködô versengés fogalmának a leírása, az ebben közrejátszó kapcsolati és szituációs tényezôknek a feltárása (Fülöp, 2008; Fülöp és Orosz, 2015). A pszichológiai szakirodalom korábban nem vizsgálta elmélyültebben és szisztematikusan, hogy a gyôzelemre és a vesztésre milyen érzelmi és viselkedéses válaszmintázatok lehetségesek, ezek milyen összefüggésben állnak egymással, illetve alkotnak-e egymástól eltérô megküzdési módokat. Különbözô életkorú és kulturális hátterú csoportokban azonosította a Gyôzelemmel és a Vesztéssel való Megküzdés Pszichológiai Modelljét (Fülöp és Berkics, 2007).

A hazai szervezetpszichológia lokális jellegzetessége, hogy Engländer Tibor munkásságának köszönhetôen a valószinúségi itéletek és a döntések kognitív alaptudományi kutatásában gyökerezett (Engländer, 1999; Faragó és Uatkán, 2018). A hazai kutatók a valószínúségi ítéletalkotást befolyásoló heurisztikákat vizsgálták, törekedtek a valószí- 
nûség-becslés alaki tényezôinek, s a kockázatészlelésben megmutatkozó torzítások és a laikusok és a szakértôk e téren fennálló különbségeinek feltárására. (A kockázatészlelés elsố kultúrközi összehasonlítása magyar-amerikai mintán valósult meg.) Ezen kognitív pszichológiai alapkutatások relevánsak voltak a lassan hazánkban is tért nyerô gazdaságpszichológia szempontjából is (lásd a kockázatok kezelését övezô társadalmi viták elemzését, a vállalkozói és a befektetői kockázatvállalás, valamint a rendelkezésre álló erôforrás kockázatvállalást befolyásoló hatása vizsgálatát). Folytatólagosan az ELTE-n - Faragó Klára irányításával - végzett szervezetpszichológiai kutatások gyújtópontjában a szervezet sikerességének egyéni és stratégai feltételei állnak, a gazdasági válság szervezeti kockázatvállalásra gyakorolt hatása, valamint a szervezeti sikerességgel kapcsolatos vezetôi nézetek tematizálták e kutatásokat. A szervezeti sikeresség szempontjából került elemzésre az a kérdés is, hogy a szervezeti kultúra mennyire nyit teret az egyén szervezeti aktivitásának, kezdeményezóképességének: itt többek között a pszichológiai tôke szerepét, a szervezeti változással kapcsolatos attitúdöket, valamint a szervezeti véleménynyilvánítás motivációját és szervezeti fogadtatását tanulmányozzák (Faragó, 2013; Faragó és Kovács, 2005).

\section{MORÁL, ÉRTÉK ÉS NEVELÉS}

A szervezetpszichológiának - Kovács Zoltán révén - az Engländer-múhelybôl sarjadt másik ága az igazságosság, azon belül is a szervezeti igazságosság kutatásának tematikájával foglalkozott, 30 éves távon Kovács Judit irányításával. Ennek eredményei közül a korábbi (Falk, Gächter és Kovács, 1999) kísérletek alapján mutat rá a viszonosság normájának múködésére a munkavégzéssel kapcsolatos együttmúködések szervezésében, a késôbbi (Pántya, Kovács, Kogler és Kirchler, 2016) a különbözô adórendszerek munkára és adózásra ösztönzô tulajdonságait vizsgálja kísérletesen, különös tekintettel az igazságosság szerepére. Ennek a kutatási vonulatnak támpontja volt Sallay Hedvignek az igazságos világba vetett hitre és annak mérésére irányuló tapasztalatgyújtése, melynek egyik gyakran hivatkozott eredménye, hogy szerzótársaival együtt rámutattak arra, az igazságos és az igazságtalan világba vetett hit két külön konstruktum (Dalbert, Lipkus, Sallay és Goch, 2001).

Mind az idézett debreceni, mind az alábbiakban érintett szegedi tudományos munkálatok hátterében jelen volt Váriné Szilágyi Ibolya longitudinális tapasztalatgyújtésre épülő értékkutatása, amely a szociológiai megközelítések makrostrukturális elvontságát pszichológiai látásmóddal tette teljesebbé, gazdag nemzetközi szakirodalomra támaszkodó elméleti-módszertani tudatossággal (Váriné, 2003). Az egyéni értékfelfogás és a sikerképzetek kapcsolatának vizsgálata új kutatási területet nyitott meg (Váriné, 1999).

A nevelés szociálpszichológiájának szakterületén mutat fel számos eredményt a Szabó Éva vezetésével, Kőrössy Judit érdemi közremúködésével alakuló kutatómúhely. A tanárok és a diákok szociális reprezentációjának leírása, körükben a sikeresség látni vélt tartalmának és feltételeinek felderítése képezi kutatásaik tárgyát (Szabó és Kôrössy, 2009). A siker, a felelősség és a teljesítmény sok esetben ellentmondásos kapcsolatát derítették fel iskolai közegben, és így jutottak el a tanárok és a tanulók közérzetének 
- pedagógiai, sôt tágabb közéleti jelentôségú - módszeres vizsgálatához (Jagodics és Szabó, 2014; Szabó és Kékesi, 2016).

A fơbb területek bemutatása során - ha csak szerény utalásokkal is - óhatatlanul jeleznünk kellett, hogy a hazai szociálpszichológia intellektuális támpontja és forrásvidéke lett a történeti és politikai pszichológiának (Hunyady, 1998c), a gazdaság és jog társtudományok által kifejezetten igényelt pszichológiájának (Hunyady és Székely, 2003; Hunyady és Berkics, 2015), illetve a munka és nevelés világában új hajtásként a szervezetpszichológia és a pedagógiai szociálpszichológia múvelésének (Mészáros, 2004; N. Kollár és Szabó, 2004).

Összefoglalóan megállapíthatjuk, hogy az amerikai szaktudomány kezdeteitôl 60, az európai térhódítástól 15 éves elmaradásban lévô magyar szociálpszichológia a 90-es években már beleszövôdött a nemzetközi tudományosságba, sôt ahhoz több területen kezdeményezó módon járult hozzá. A laboratóriumi kísérletezés nem tartozik az erôsségei közé, de a fố trend alakulásával összhangban a többváltozós leiró elemzések terén korszerú eszközöket használ, kifejezetten előnyös tradíciója a nagyminták alkalmazása és a társadalmi változók kontrolljára fordított figyelem. Szaporodnak az impaktfaktoros folyóirat-közleményei, de minden tudományközi összehasonlításban örvendetes eredményeket könyvelhet el a szó szoros értelmében vett monográfiák magyar és idegen nyelven való közzétételében, ami a tárgyában átfogó és elméletileg igényes szociálpszichológiai kutatások bemutatásának adekvát formája. A szakterület a maga szemléleti sokszínúségével és nemzetközi nyitottságával jelen van az egyetemi képzésben, és egyszersmind betölti azt a szerepet is, amely a sokszínú euroatlanti ember- és társadalomfelfogás hazai megjelenítésében rá hárul. A társadalmi változások problematikus pontjainak (az elôítéletesség, a versenyszellem és a politikai aktivitás korlátai) megvilágításában és kritikai elemzésében kompetenciájának keretei között tevôlegesen részt vállal.

\section{IRODALOM}

Borgos, A., Erôs, F., \& Gyimesi, J. (Eds) (2019). Psychology and Politics: Intersections of Science and Ideology in the History of Psy-Sciences. Budapest, New York: Central European University Press.

Borgos, A., Erôs, F., \& Litván, Gy. (Eds) (2006). Mérei élet-mú. Tanulmányok. Budapest: Új Mandátum Könyvkiadó.

Csepeli, Gy. (1992). Nemzet által homályosan. Budapest: Századvég Kiadó.

Csepeli, Gy. (1997a). National identity in contemporary Hungary. New York (NY): Columbia University Press, Social Science Monographs, Atlantic Research and Publications (ARP).

Csepeli, Gy. (1997b). Szociálpszichológia. Budapest: Osiris Kiadó.

Csepeli, Gy. (2020). Ember 2.0: A mesterséges intelligencia gazdasági és társadalmi hatásai. Budapest: Kossuth Kiadó.

Csepeli, Gy., Murányi, I., \& Prazsák, G. (2011). Új tekintélyelvüség a mai Magyarországon. Budapest: Apeiron.

Csepeli, Gy., \& Örkény, A. (2017). Nemzet és migráció. Budapest: ELTE TÁTK.

Csepeli, Gy., \& Örkény, A. (2020). Nation and Migration: How Citizens in Europe Are Coping with Xenophobia. Budapest: Central European University Press.

Csepeli, Gy., \& Prazsák, G. (2010). Örök visszatérés? Társadalom az információs korban. Budapest: Jószöveg Múhely Kiadó. 
Dalbert, C., Lipkus, I. M., Sallay, H., \& Goch, I. (2001). A just and an unjust world: Structure and validity of different world beliefs. Personality and Individual Differences, 30(4), 561-577.

Dessewffy, T. (2019). Digitális szociológia. Szociológiai képzelet a digitális korban. Budapest: Typotex.

Engländer, T. (1999). Viaskodás a bizonytalannal. A valószinúségi itéletalkotás egyes pszichológiai problémái. Budapest: Akadémiai Kiadó.

Enyedi, Z., \& Erôs, F. (Eds) (1999). Authoritarianism and prejudice: Central European perspectives. Budapest: Osiris Kiadó.

Erôs, F. (1993). A válság szociálpszichológiája. Budapest: T-Twins Kiadó.

Erôs, F. (2001a). Analitikus szociálpszichológia: Történeti és elméleti tanulmányok. Budapest: Új Mandátum Könyvkiadó.

Erôs, F. (2001b). Az identitás labirintusai: Narratív konstrukciók és identitás-stratégiák. Budapest: Osiris/Janus.

Erôs, F. (2007). Trauma és történelem: Szociálpszichológiai és pszichoanalitikus tanulmányok. Budapest: Jószöveg Múhely Kiadó.

Erôs, F., Lénárd, K., \& Bókay, A. (Eds) (2008). Typus Budapestiensis: Tanulmányok a pszichoanalizis Budapesti Iskolájának történetérôl és hatásáról. Budapest: Thalassa Alapítvány.

Falk, A., Gächter, S., \& Kovács, J. (1999). Intrinsic motivation and extrinsic incentives in a repeated game with incomplete contracts. Journal of Economic Psychology, 20(3), 251-284.

Faragó, K. (Ed.) (2013). Szervezet és pszichológia - új irányzatok az ezredfordulón. I. és II. kötet. Budapest: ELTE Eötvös Kiadó.

Faragó, K., \& Kovács, Z. (Eds.) (2005). Szervezeti látleletek - a szervezetpszichológia hazai kutatási irányzatai. Budapest: Akadémiai Kiadó.

Faragó, K., \& Uatkán A. (2018). Risk taking with variable resources: a field and a laboratory experiment. Open Psychology, 1(1), 36-57.

Fülöp, É., \& Kôvvágó, P. (2018). A kollektív áldozati szerep szociálpszichológiája. Budapest: Oriold és Társai Kft.

Fülöp, M. (1992). Teacher's Concepts on Competition. Didaktisk Tydskrift, 9, 46-57.

Fülöp, M. (2002). Intergenerational differences and social transition: Teachers' and students perception of competition in Hungary. In Nasman, E., \& Ross, A. (Eds), Children's understanding in the new Europe (pp. 63-89). Stoke-on-Trent: Trentham Books.

Fülöp, M. (2005). The development of social, economical, political identity among adolescents in the post-socialist countries of Europe. In Fülöp, M., \& Ross, A. (Eds), Growing up in Europe today: Developing identities among adolescents (pp. 11-39). Stoke-on-Trent: Trentham Books and Sterling.

Fülöp, M. (2008). Educating the cooperative competitive citizen. In Tirri, K. (Ed.), Educating moral sensibilities in urban schools (pp. 171-187). Rotterdam: Sense Publishers.

Fülöp, M., \& Berkics, M. (2007). A gyôzzelemmel és a vesztéssel való megküzdés mintázatai serdülókorban. Pszichológia, 27(3), 199-220.

Fülöp, M., \& Orosz, G. (2015). State of the art in competition research. In Scott, R., \& Kosslyn, S. (Eds), Emerging Trends in the Social and Behavioral Sciences (pp. 1-16.). Hoboken: John Wiley and Sons.

Garai, L. (1993). „...elvegyültem és kiváltam”: Társadalomlélektani esszé az identitásról. Budapest: T-Twins.

Hadarics, M., \& Kende, A. (2019). Negative stereotypes as motivated justifications for moral exclusion. The Journal of Social Psychology, 159(3), 257-269.

Halász, L. (1992). Hasonmás: Az ember kettốssége. Budapest: Scientia Humana Társulás.

Hunyady, Gy. (1996). Sztereotípiák a változó közgondolkodásban. Budapest: Akadémiai Kiadó.

Hunyady, Gy. (1998a). Stereotypes during the decline and fall of communism: International Series of Experimental Social Psychology. New York/London: Routledge.

Hunyady, Gy. (1998b). Characterization of Social Categories in Psychological and Societal Context. Budapest: Eötvös Loránd University. 
Hunyady, Gy. (Ed.) (1998c). Történeti és politikai pszichológia. Budapest: Osiris Kiadó.

Hunyady, Gy. (2002). A kontraszelekció pszichológiája. Magyar Pszichológiai Szemle, 57(3), 397-434.

Hunyady, Gy. (2006). A szociálpszichológia történeti olvasatai. Budapest: ELTE Eötvös Kiadó.

Hunyady, Gy. (2018). Rendszerigazolás és rendszerkritika. Magyar Pszichológiai Szemle, 73(2), 269-298.

Hunyady, Gy., \& Berkics, M. (Eds) (2015). A jog szociálpszichológiája: a hiányzó láncszem. Budapest: ELTE Eötvös Kiadó.

Hunyady, Gy., \& Székely, M. (Eds) (2003). Gazdaságpszichológia. Budapest: Osiris Kiadó.

Jagodics, B., \& Szabó, É. (2014). Job demands versus resources: workplace factors related to teacher burnout. Practice and Theory in Systems of Education, 9(4), 377-390.

Kende, A., Hadarics, M., Bigazzi, S., Boza, M., Kunst, J. R., Lantos, A. N., et al. (2020). The last acceptable prejudice in Europe? Anti-Gypsyism as the obstacle to Roma inclusion. Group Processes \& Intergroup Relations, 1368430220907701.

Kiss, P. (2019). Hármasugrás. A magyar szociálpszichológia csúcsteljesítményei és recepciójuk itthon és külföldön. In Pléh, Cs., Mészáros, J., \& Csépe, V. (Eds), A pszichológiatörténet-írás módszerei és a magyar pszichológiatörténet (pp. 262-310). Budapest: Gondolat Kiadó.

Kovács, J., \& Pántya, J. (2012). A vesztes-szerep mintázatai magyar történelmi események értékelésében. In Kovács, J., \& Münnich, Á. (Eds), Nemzeti emlékezethelyek: attitüdök, reprezentációk, élmények, funkciók, struktúrák (33-56). Debrecen: Debreceni Egyetemi Kiadó.

Krekó, P. (2018). Tömegparanoia. Az összeesküvés-elméletek és álhirek szociálpszichológiája. Budapest: Athenaeum.

László, J. (2008). The science of stories: An introduction to narrative psychology. New York, London: Routledge.

László, J. (2005). A történetek tudománya: Bevezetés a narratív pszichológiába. Budapest: Új Mandátum Könyvkiadó.

László, J. (2014). Historical Tales and National Identity: An introduction to narrative social psychology. London: Routledge.

Lengyel, Zs. (1997). Szociálpszichológia szöveggyújtemény. Budapest: Osiris Kiadó.

Mészáros, A. (2004). Az iskola szociálpszichológiai jelenségvilága. Budapest: ELTE Eötvös Kiadó.

Münnich, Á. (1995). Satisfaction in Debrecen, Hungary. In Saris, W. E., Veenhoven, R., Scherpenzeel, A. C., \& Bunting, B. (Eds), A comparative study of sarisfaction with life in Europe (pp. 195-200), Budapest: ELTE Eötvös Kiadó.

Münnich, Á., Maksa, G., \& Mokken, R. J. (1999). Collective judgement: combining individual value judgements. Mathematical Social Sciences, 37(3), 211-233.

Nguyen Luu, L. A. (2019). A nemzetközi felsôoktatási mobilitás pszichológiai aspektusai. Budapest: ELTE Eötvös Kiadó.

N. Kollár, K., \& Szabó, É. (2004). Pszichológia pedagógusoknak. Budapest: Osiris Kiadó.

Pántya, J., Kovács, J., Kogler, C., \& Kirchler, E. (2016). Work performance and tax compliance in flat and progressive tax systems. Journal of Economic Psychology, 56, 262-273.

Pataki, F. (1993). Rendszerváltás után. Társadalomlélektani terepszemle. Budapest: Scientia Humana.

Pataki, F. (2000). Rendszerváltók és bünbakok: Társadalom-lélektani metszetek. Budapest: Osiris Kiadó.

Pataki, F. (2001). Élettörténet és identitás. Budapest: Osiris Kiadó.

Pataki, F. (2004). Érzelem és identitás. Budapest: Új Mandátum Könyvkiadó.

Pataki, F. (2005). A Nékosz-legenda. Budapest: Osiris Kiadó.

Pataki, F. (2011). A varázsát vesztett jövố. Budapest: Noran Libro Kiadó.

Pataki, F. (2013). Hosszú menetelés: a Fidesz-jelenség: társadalomlélektani vázlat. Budapest: Noran Libro Kiadó.

Pléh, Cs., \& Unoka, Zs. (Eds) (2016). Hány barátod van? Budapest: Oriold és Társai Kft. 
Szabó, É., \& Kékesi, M. (2016). A felelôsség koncentrikus szerkezetének vizsgálata középiskolások körében. Alkalmazott Pszichológia, 16(2), 53-68.

Szabó, É., \& Kőrössy, J. (Eds) (2009). Ezerarcú reprezentáció. Szeged: JatePress.

Szabó, M., \& Kovács, M. (2017). A feminizmus szociálpszichológiája: attitúdök, identitás és cselekvés. In Kovács, M. (Ed.), Társadalmi nemek. Elméleti megközelitések és kutatási eredmények (pp. 171-186). Budapest: ELTE Eötvös Kiadó.

Ujhelyi, A. (2014). A Facebook szociálpszichológiája. Szakirodalmi összefoglaló. Alkalmazott Pszichológia, 14(1), 113-132.

Váriné Szilágyi, I. (1999). Az individualizmus különbözô formái a sikerképzetekben. In Solymosi, Zs. (Ed.), A siker lélektana (pp. 204-227). Budapest: Új Mandátum Kiadó.

Váriné Szilágyi, I. (Ed.) (2003). Értékek az életben és a retorikában. Budapest: Akadémiai Kiadó.

\section{SOCIAL PSYCHOLOGY AND BOUNDARY AREAS}

\section{HUNYADY, GYÖRGY}

The last three decades of social psychology can be characterised by specific thematic directionsin Hungary. The first direction includes different aspects of social identity (generational, national, cultural, gender), intergroup relationships between these macrostructural social groups, stereotypes and the mechanisms of the multiculturial education. The second major thematic unite encompasses the social psychology of change, both the societal-political change after the "fall of communism", and the revolutionary effects of the internet, and the technology of communcation in general. The third important field is the dynamics of the interpersonal and organizational behavior, with a special regard to the cooperation-competion continuum. The fourth trend involves the personal values, their role in the individuals' world views, and the transmission of values via education. During this period a significant methodolodical development took place and the interdisciplinary relations strengthened among social psychology and other social sciences (especially educational science, economy and law).

Keywords: thematic orientations, social identity, social change, interpersonal and organziational dynamics, personal values and value transmission

A cikk a Creative Commons Attribution 4.0 International License (https://creativecommons. org/licenses/by/4.0/) feltételei szerint publikált Open Access közlemény, melynek szellemében a cikk bármilyen médiumban szabadon felhasználható, megosztható és újraközölhetô, feltéve, hogy az eredeti szerzô és a közlés helye, illetve a CC License linkje és az esetlegesen végrehajtott módosítások feltüntetésre kerülnek. (SID_1) 